\title{
Challenges and Prospects of Technical and Vocational Education and Training (TVET): Evidence from Sawla TVET College, Gamo Gofa Zone, SNNPRS, Ethiopia
}

\author{
Dawit Fantaye (MA in Development Management) \\ Higher Government Expert @ SNNPRS of Ethiopia \\ Hawassa, Ethiopia
}

\begin{abstract}
The main purpose of this study was to assess the challenges and prospects of Sawla TVET College located at Sawla town administration, South Nations Nationalities and Peoples Regional State. The study used descriptive survey method through both quantitative and qualitative approach. The current trainees and senior graduates of the college who are engaged at work in the study area were taken as sample frame from which 253 samples were selected using stratified and simple random sampling methods based on the strata of the population. The current trainees and senior graduates who are engaged at work, the trainers, college management, local government officials, unemployed youths and community representatives were selected as primary data sources whereas secondary data were collected from document analysis of the college and local government. Quantitative data were collected using Questionnaires and the qualitative data via interview, focus group discussions and observations. The collected data were analyzed by descriptive statistics using SPSS version 21 which provided the frequency count and the percentage of the responses. The major findings of the study shows that the perception of the public concerning TVET is discouraging that looks it as place of last resort for those who have no were to go, awareness creation of the stakeholders is weak, low access of job in the area is another demotivating factor of the youth not to join TVET, and hence the enrollment of the college is below the target. The trainees are selective in streaming thinking of the job opportunity after completion of the training. The integration of the TVET College with stakeholders is very weak and hence, they are not delivering their responsibilities. The internal capacity of the college is not satisfactory in that it lacks qualified trainers, unavailability of well-functioning machines, and provision of raw materials for practical skills training is not timely and enough. Finally, the study recommends the TVET together with the local government to work on awareness creation of the society about the TVET, to strengthen the integration with stakeholders for increased intake of trainees, employability of the graduates, provision of quality training and industry extension and deal with the region to develop its internal capacity. Addressing these issues would make the future prospect of Sawla TVET College better than ever before.
\end{abstract}

Keywords: Sawla TVET College, Skilled manpower, Employment, MSEs, Industry extension,

DOI: $10.7176 / \mathrm{JESD} / 10-5-02$

Publication date:March $31^{\text {st }} 2019$

\subsection{BACKGROUND OF THE STUDY}

The trendiest issue for National Governments, donors and other actors in the developing world is poverty alleviation. Although Technical and Vocational Education and Trainings (TVETs) were initiated for the quest of ensuring efficiency and profit in industrial mode through providing skilled human capital to industries, it is now evolved into an important tool to reduce poverty (UNESCO, 2013:15). In order to translate TVET skills into a poverty alleviation weapon, there has to be transformation of individual lives which hierarchically expands into community level sustainable change. Because it is through the transformation of individuals that families are transformed, and they in turn collectively transform communities. Growth patterns skewed with inequality will not meaningfully and inclusively alleviate poverty and do contrary to the effective TVET impacts (UNESCO, 2013:315).

Being one of the developing nations in the world, with $33 \%$ of its population living on less than $\$ 1.25$ a day (World Bank, 2015:19), the Government of Ethiopia (GoE) also needs the TVET program to contribute to enable it actively participate in the competitive global market economy which requires technical and professional citizens trained in the "ability to learn" and fit into specific occupation (EFA, 2015:12).

As mentioned in the Education Sector Development Plan (ESDP) IV, the main objective of TVET is to train middle level human power and transfer demanded technologies to contribute to the Growth and Transformation Plans (GTP 1\&2) as well as the vision of the country to become a middle income country in the year 2025 as reported in (EFA, 2015: 21) through producing marketable and entrepreneurial skills as well as creating appropriate composition of skills in the transiting economy from agriculture-based to industrialization. The GoE believes that the TVET is an agent in technology acquisition, accumulation, transfer and centers for marketable and entrepreneurial skillsproviding training on market oriented programs based on the demand of the 
industry (MoE, ESDP IV: 66). As the socio-economic characteristics of the enrolling students and the operational environment of the TVETs differ, closer look at various cases is important to draw differentiated and area specific lessons. As Ethiopia is socio-economically and bio-physically so diverse, studies in one region cannot be taken as a replica for the other region. The above studies also addressed specific issues as challenges and contributors to positive prospects.

Therefore, this study addresses the challenges and prospects of TVET in terms of its contribution to economic development particularly in producing skilled sufficient manpower, taking one of 45 public TVET institutions in SNNPR state, the case of Sawla TVET College in Gamo Gofa Zone, Sawla town administration.

\subsection{STATEMENT OF THE PROBLEM}

Following the development of the TVET policy and strategy, the GoE presumes that the programs would run effectively and meet the intended objectives. It assumes that the TVETs would serve as sources of employable skills and hence would contribute to the reduction of the unemployment rate. However, the country's unemployment rate remains high although it reduced from $17.40 \%$ in 2012 to $16.80 \%$ in 2015 (WB, 2015: 27). Moreover, there are reports verifying that the presumptions of the technological and economic utility of the TVETs are challenged by various drawbacks both at designing and implementation phases of the program (Yostena, 2014: 9; Awraris, 2014:15; Fita, 2014:64). Educan (2009: 20) indicated that a systematic integration of TVET with the world of work has not yet been achieved. Most curricula used in formal TVET were not developed based on occupational standards. The report also argued that the plan for attaching the TVET programs to industrial plants has not been fully materialized due to lack of cooperation of the employers as they were not consulted during the planning process. Other studies have shown that many TVET graduates remain unemployed even in those occupational fields that show a high demand for skilled manpower (Eden, 2012:42), (Educan, 2009:20). Lemma (2014: 175) on his part indicated that weak preparation of teaching learning materials, poor implementation of principles of competency based training,TVET institutions and industry linkage. He evidenced that this has been reflected in students' poor performance COC assessments.

With the general view of challenge stories from other areas such as the Addis Ababa City Administration, Oromia region, this study aims to look into the challenges and prospects of the Sawla TVET College. The preliminary assessment at the college (the annual performance reports of 2012-2016 and statistical data of the College) indicated that the TVET College is experiencing less number of trainees' enrollment in most of its academic years than the targeted plan of action that hampers the efficiency of the institution.

The other problem observed at the College is related to the link between the TVET and the job environment. The current data from the Sawla Town administration MSE facilitators show that among 2,202 youths who are at work in different enterprises, only 380 are graduates of the nearby Sawla TVET College (Sawla Town MSE performance report, 2013-2016). In addition, there are about 348 trained graduates from the TVET College who are still living jobless in the town. This shows that there is observed gap between demand and supply and resulting in heightening the unemployment of the town due to the 994 non-trained youths (only in the Sawla town) and the jobless graduates.

The stated problems above indicate that there are still gaps of understanding and integration which are retarding the envisaged effectiveness of the TVET strategy and the implementation mechanism. Therefore, this study is concerned with filling the gap through assessing the challenges of Sawla TVET College that hinder it from achieving strategic and operational goals. Also, as this is the strategic direction set by the government to create more employable skills and scarce resources have been invested in the program, the future prospects of the TVET College towards meeting objectives is also assessed in the study.

\subsection{OBJECTIVES OF THE STUDY}

The overall objective of the study is to assess the challenges and prospects of Sawla TVET College in producing skilled and employable manpower.

The Specific objectives of this study are the followings:

* To assess the employability status of the TVET graduates in the study area.

* To examine the integration of Sawla TVET College and other concerned or mandated stakeholders to make efficient use of the institution

* To investigate the awareness or perceptions of the trainees, the local government officials and other concerned stakeholders regarding the strategic benefit of the TVET.

* To identify the challenges of the internal capacity of the College in terms of adequacy of qualified teachers, workshops, machines, and class rooms in Sawla TVET College.

* To point out the opportunities for the future prospect of Sawla TVET College. 


\subsection{REVIEW OF RELATED LITERATURE:}

\subsubsection{History, Concept and Definition of TVET}

UNESCO, as a lead international agency for education including TVETs, defines TVET as "those aspects of the educational process involving, in addition to general education, the study of technologies and related sciences and the acquisition of practical skills, attitudes, understanding and knowledge relating to occupation in various sectors of economic life". TVET thus is a program that equips people, especially of the youth, not only with vocational skills, but with a broad range of knowledge, skills and attitudes that are now recognized as indispensable for meaningful participation in work and life (UNESCO, 2014: 5). The expected imperatives of TVET have been portrayed in national and continental strategies. The African Union in its continental TVET strategy highlighted that today; TVET is believed to be one of the pivotal strategies for many developing countries to support young people to acquire employable professional skills (AU strategy, 2007: 38). The same strategy discussed that there are emerging wide-range of issues of demand and supply of skills; employability, improving skills, and ability for self-employment are being addressed under TVET. The same strategy grounds that TVET is an integral and final purpose of any education system that leads to the acquisition of knowledge and expertise relevant to society and the development of the individual. Additional work by Nuffic highlighted that TVET prepares learners for jobs that are based in manual or practical activities related to a specific trade, occupation or vocation in which the learners participate (Nuffic, 2010: 1-2).

In sum, the TVET which was initiated to supply human capital required for industry in Europe and North America is now considered as integral part of the general education for employable skill development (UNESCO, 2011: 4), TVET which covers aspects of technologies and the acquisition of practical skills and knowledge relating to occupation in various sectors of economic life and world of work. Nonetheless, there are several issues compounding the effectiveness of the TVET as there is observed paradox of believing in the imperativeness of the program for sustainable development but failure to commit required attention and resources by the national governments.

\subsubsection{The Expected Roles of TVET in Producing Skilled Manpower}

According to Ogubnaya and Eskereobong(2015:6), TVET has been accepted globally as a strong catalyst to development and sustainable national security and viable strategy for tackling the pervasive youth unemployment because of its potentials in job creation, wealth generation, poverty reduction and technological transformation. The work by Afeti (2016:2) has also affirmed that TVET is the most practical avenue for acquiring readily employable skills for the world of work. UNESCO/UNEVOC $(2013,11)$ stated that lack of skills that are valued in global and local economies constrains economic growth, jobs, and income. Good, demand-driven TVT is potentially one of the most important tools for developing young people's skills.

The World Bank in its 2004 comprehensive study demonstrated that the TVET program is believed to make useful contributions to development by way of equipping the youth with employable skills into the labor market (WB, 2004: 127). The same study underscored that TVET programs are instrumental in providing skills required to improve access to employment opportunities, improve productivity, and raise income levels of the poor families. Afeti (2016:3-4) indicated broader role of TVETs for Africa. He explained that apart from being the most practical avenue for acquiring readily employable skills for the work world, it is important tool to drive the agenda of transforming African economies through value-addition to their primary commodities and natural resources. Moreover, the availability of skilled workforce can be a major pull factor for Foreign Direct Investment (FDI). For example, the report added, revitalizing the manufacturing, agriculture and agroprocessing sectors in Africa offers enormous possibilities for industrialization and employment generation.

\subsubsection{Prevailing Africa's Concern on TVET}

Like other developing regions of the world, Africa has its challenges regarding skills development. The World Bank report indicated that principal challenge for African economies over the next decade is to find productive employment for the 7 to 10 million annual new entrants to the labor force-a consequence of historical rapid population growth and a swelling of the labor force by today's school-leavers(World Bank, 2004:27).

Afeti (2016: 3-4) furthered the observation and concluded that growing problem of youth unemployment in Africa is a major concern of many governments. Over 10 million young Africans, often poorly skilled, leave the school system every year in search of jobs in local employment markets which are not expanding fast enough to create jobs. Many of these job seekers lack the requisite skills employers want. Without employment-related skills, school leavers cannot benefit from even the minimal employment opportunities that may be available to job seekers.

UNESCO's International Institute for Capacity Building in Africa (IICBA) unit also conducted an Africawide study and concluded that in most of African countries, primary enrolment has significantly increased, but general secondary education does not have enough space nor provide education to guarantee employment. Therefore, the only way to respond to the growing demand for relevant education is to devise new TVET strategies for the youth to access the world of work (UNESCO-IICBA, 2011:1). 


\subsubsection{Challenges of Technical and Vocational Education and Training (TVET)}

UNESCO (2011:3) indicated that apart from the localized physical and financial constraints, the $21^{\text {st }}$ century presents a radically different economy and society which is likely to have profound implications on TVETs. The TVETs therefore must adapt to these key features of the time which include globalization and sustainability, ICT revolution, emergence of knowledge sociality and rapid knowledge obsolesce.

In order to align the selected literature review to the research questions and objectives of this study, the review is done under the following headlines:

- TVET Stakeholder's Attitudes or perceptions

- Employability of skills of the TVET graduates

- Integration status of the TVET with other relevant sectors

- Experiences related to Leadership and Governance the TVETS

1.4.5. Conceptual Framework of the Study

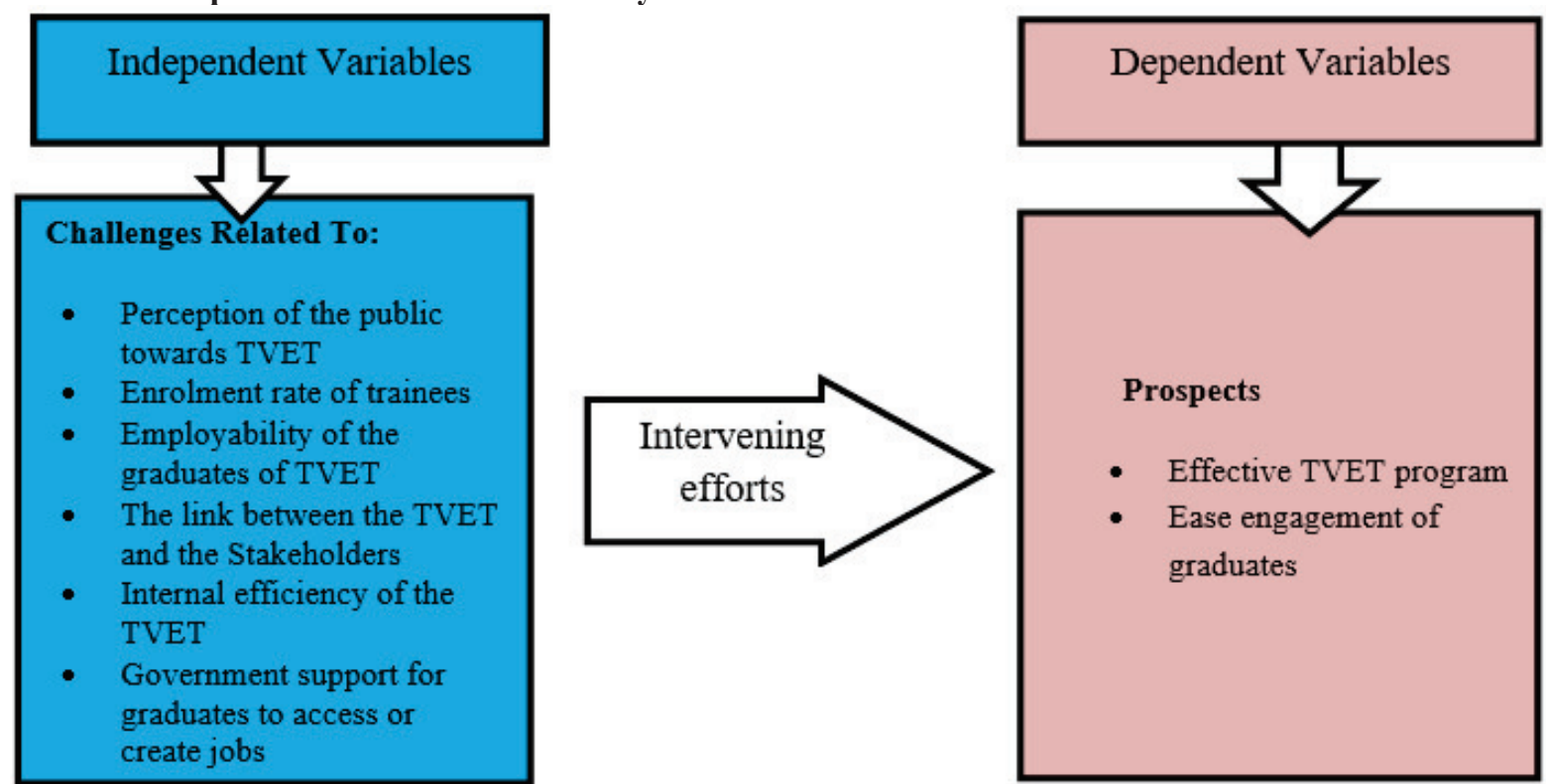

Figure 1: Conceptual Framework of the Study

Source: Researcher's Own Construction based on Literature Review

\subsection{RESEARCH METHEODOLOGY}

The study adopted both qualitative and quantitative survey design as it aims at collecting information from respondents. The quantitative methods were used to measure quantifiable parameters and the qualitative observations were used to gauge opinions/views, respectively. Frequencies and percentages were used to assess the respondents based on data collected through questionnaire. Qualitative methods were used to describe and analyze the information obtained through interviewing, focus group discussion and observations. By using the formula of sample size determination formula of Yamane (1967:886), from the total 685 sampling frame, 253 respondents were selected and determined to be the sample size and is shared among the trained youths who are engaged at work and the current graduating class trainees of the TVET by probability proportional to size (PPS) and stratified sampling to their field of specializations.

That is;

$n=\frac{N}{=1+N(\theta) 2}$ where $\mathrm{n}=$ is sample size,

$\mathrm{N}=$ population and,

$\mathrm{e}=$ level of precision that is 0.05 and assumed $95 \%$ confidence level.

$n=\frac{685}{1+685(0.05) 2} \approx 253$

The total sample size is shared by probability proportional to size for those engaged at work having trained and the current graduating class trainees of the College, that is, 140 from 380 and 113 from 305, respectively were selected.

\subsection{DATA ANALYSIS AND DISCUSSION}

In conducting the study, 253 questionnaires were distributed out of which 253 were returned and answered. Therefore, the response rate is $100 \%$. 
1.6.1. Enrollment trend of the College in the last 4 consecutive years (The years are in Ethiopian Calendar; E.C.)

Table 1: Enrolment Trends of the College in the last 4 years

\begin{tabular}{|c|c|c|c|c|c|c|c|c|c|}
\hline \multirow{2}{*}{$\begin{array}{l}\text { Field of } \\
\text { specialization }\end{array}$} & \multirow[b]{2}{*}{ Level } & \multicolumn{2}{|c|}{2006 E.C. } & \multicolumn{2}{|c|}{2007 E.C. } & \multicolumn{2}{|c|}{2008 E.C. } & \multicolumn{2}{|c|}{2009 E.C. } \\
\hline & & Plan & Registered & Plan & Registered & Plan & Registered & Plan & Registered \\
\hline \multirow[b]{3}{*}{ Industry } & $1 \& 2$ & 579 & 40 & 890 & 82 & 450 & 133 & 390 & 79 \\
\hline & $3 \& 4$ & --- & --- & --- & --- & --- & --- & --- & --- \\
\hline & $\begin{array}{l}\text { Sum } \\
\%\end{array}$ & 579 & $\begin{array}{l}40 \\
7 \%\end{array}$ & 890 & $\begin{array}{c}82 \\
9.2 \%\end{array}$ & 450 & $\begin{array}{c}133 \\
29 \%\end{array}$ & 390 & $\begin{array}{c}79 \\
20 \%\end{array}$ \\
\hline \multirow[b]{3}{*}{ Construction } & $1 \& 2$ & 1770 & 175 & 1145 & 181 & 709 & 351 & 499 & 151 \\
\hline & $3 \& 4$ & 335 & 21 & 103 & 30 & 166 & 166 & 205 & 37 \\
\hline & $\begin{array}{l}\text { sum } \\
\%\end{array}$ & 2105 & $\begin{array}{c}196 \\
9.3 \%\end{array}$ & 1248 & $\begin{array}{c}211 \\
17 \%\end{array}$ & 875 & $\begin{array}{c}517 \\
58 \%\end{array}$ & 704 & $\begin{array}{c}188 \\
25 \%\end{array}$ \\
\hline \multirow{3}{*}{ Surveying } & $1 \& 2$ & 50 & 48 & --- & --- & 100 & 109 & 50 & 77 \\
\hline & $3 \& 4$ & --- & --- & 40 & 36 & 80 & 76 & 100 & 106 \\
\hline & $\begin{array}{l}\text { Sum } \\
\%\end{array}$ & 50 & $\begin{array}{c}48 \\
96 \%\end{array}$ & 40 & $\begin{array}{c}36 \\
90 \%\end{array}$ & 180 & $\begin{array}{c}185 \\
103 \%\end{array}$ & 150 & $\begin{array}{c}183 \\
122 \%\end{array}$ \\
\hline \multirow[b]{3}{*}{ ICT } & $1 \& 2$ & 40 & 45 & --- & --- & 40 & 52 & --- & --- \\
\hline & $3 \& 4$ & 40 & 41 & 80 & 83 & 120 & 155 & 80 & 94 \\
\hline & $\begin{array}{l}\text { Sum } \\
\%\end{array}$ & 80 & $\begin{array}{c}86 \\
107 \%\end{array}$ & 80 & $\begin{array}{c}83 \\
103 \%\end{array}$ & 160 & $\begin{array}{c}207 \\
129 \%\end{array}$ & 80 & $\begin{array}{c}94 \\
117 \%\end{array}$ \\
\hline
\end{tabular}

Source: Sawla TVET College record center and Annual reports (2006 E.C. -2009.E.C.)

1.6.2. Parameters and Challenges affecting enrollment of trainees in the College

Table 2: Parameters and Challenges affecting enrollment of trainees in the College $(n=113)$

\begin{tabular}{|c|c|c|c|}
\hline No Items & Responses & Frequency & Percent \\
\hline \multirow{2}{*}{ 1. knowledge about TVET } & Yes & 53 & 46.9 \\
\hline & No & 60 & 53.1 \\
\hline \multirow{7}{*}{$\begin{array}{l}\text { 2. Insisted/motivated to join } \\
\text { the TVET }\end{array}$} & Own interest to gain knowledge and skill & 33 & 29.2 \\
\hline & For there is no other option & 7 & 6.2 \\
\hline & Parental or relatives push & 7 & 6.2 \\
\hline & Government's mobilization & 1 & 0.9 \\
\hline & Better benefiting of senior graduates Those & & 56.6 \\
\hline & engaged at work & 64 & 0.9 \\
\hline & Peer groups influence & 1 & \\
\hline \multirow{2}{*}{$\begin{array}{l}\text { 3. Selection of field by own } \\
\text { Interest }\end{array}$} & Yes & 74 & 65.5 \\
\hline & No & 39 & 34.5 \\
\hline \multirow{3}{*}{$\begin{array}{l}\text { 4. Trainees selectivity in } \\
\text { field streaming }\end{array}$} & $\begin{array}{l}\text { Expected job opportunity after completion of } \\
\text { training }\end{array}$ & 103 & 91.2 \\
\hline & Easier to understand & 5 & 4.4 \\
\hline & Lack of know how & 5 & 4.4 \\
\hline \multirow{3}{*}{$\begin{array}{l}\text { 5. Trainees give equal } \\
\text { preference to all fields }\end{array}$} & Yes & 38 & 33.6 \\
\hline & No & 75 & 66.4 \\
\hline & Strongly agree & 2 & 1.8 \\
\hline \multirow{4}{*}{$\begin{array}{l}\text { 6.Trainees interest in } \\
\text { Industry } \\
\text { and Construction than } \\
\text { Surveying and ICT }\end{array}$} & Agree & 7 & 6.2 \\
\hline & Undecided & 12 & 10.6 \\
\hline & Disagree & 53 & 46.9 \\
\hline & Strongly disagree & 39 & 34.5 \\
\hline \multirow{3}{*}{$\begin{array}{l}\text { 7. Trainees streaming in the } \\
\text { field of specializations }\end{array}$} & By trainees own choice & 74 & 65.5 \\
\hline & Based on grade point & 35 & 31 \\
\hline & By the decision of the College & 4 & 3.5 \\
\hline \multirow{3}{*}{$\begin{array}{l}\text { 8. Interested in joining the } \\
\text { TVET College }\end{array}$} & Yes & 49 & 43.4 \\
\hline & No & 64 & 56.6 \\
\hline & Lack of information & 15 & 13.3 \\
\hline \multirow{3}{*}{$\begin{array}{l}\text { 9. Reason for the respondents } \\
\text { friends not joined the TVET }\end{array}$} & Lack of interest to join the TVET & 44 & 39 \\
\hline & Worry about the challenge to get job & 43 & 38 \\
\hline & others & 11 & 9.7 \\
\hline
\end{tabular}

Source: Researcher's own survey in Sawla, 2017 
1.6.3. Employability: Preferences and Challenges in the view of current trainees

Table 3: Employability of TVET graduates in the local area $(n=113)$

\begin{tabular}{|c|c|c|c|}
\hline Items & Responses & Frequency & Percent \\
\hline \multirow{5}{*}{ 1. Employability preference } & To be employed in government office & & \\
\hline & To be self- employed/create own job & 77 & 68.1 \\
\hline & & 35 & 31.0 \\
\hline & To be employed in private sectors & & \\
\hline & & 1 & 0.9 \\
\hline \multirow{5}{*}{$\begin{array}{l}\text { 2. Extent of challenge to be } \\
\text { engaged at work }\end{array}$} & Very high & 63 & 55.8 \\
\hline & High & 35 & 31.0 \\
\hline & Moderate & 7 & 6.2 \\
\hline & Low & 4 & 3.5 \\
\hline & Very low & 4 & 3.5 \\
\hline \multirow{5}{*}{$\begin{array}{l}\text { 3. Getting employed after } \\
\text { graduation is easy }\end{array}$} & Strongly agree & 8 & 7.1 \\
\hline & Agree & 7 & 6.2 \\
\hline & Undecided & 30 & 26.5 \\
\hline & Disagree & 42 & 37.2 \\
\hline & Strongly disagree & 26 & 23.0 \\
\hline \multirow{4}{*}{$\begin{array}{l}\text { 4. Reasons for the extent of } \\
\text { challenges to be engaged at work } \\
\text { to be high and very high }\end{array}$} & Lack of job access & 72 & 63.7 \\
\hline & Lack of initial finance & 34 & 30.0 \\
\hline & Lack of market access & 2 & 1.8 \\
\hline & Lack of working place & 5 & 4.4 \\
\hline
\end{tabular}

Source: Researcher's own survey in Sawla, 2017

1.6.4. Employability: Opinions of the Employed Graduates

In addition to the currently training groups, this research also gathered the views of the employed TVET graduates about the employability

Table 4: Views of the employed TVET graduates about employability $(\mathrm{n}=140)$

\begin{tabular}{|c|c|c|c|}
\hline Items & Responses & Frequency & Percent \\
\hline \multirow{4}{*}{$\begin{array}{l}\text { 1. Type of employment } \\
\text { Engaged }\end{array}$} & In Government office & 31 & 22.1 \\
\hline & Self employed & 84 & 60.0 \\
\hline & Employed in private sector & 22 & 15.7 \\
\hline & Others & 3 & 2.1 \\
\hline \multirow{5}{*}{$\begin{array}{l}\text { 2. Availability of job } \\
\text { access in the local area }\end{array}$} & Strongly agree & 6 & 4.3 \\
\hline & Agree & 12 & 8.6 \\
\hline & Undecided & 29 & 20.7 \\
\hline & Disagree & 75 & 53.6 \\
\hline & Strongly disagree & 18 & 12.9 \\
\hline \multirow{3}{*}{$\begin{array}{l}\text { 3. Preference of } \\
\text { employment opportunity }\end{array}$} & To be employed in government office & 67 & 47.9 \\
\hline & Self- employment by creating own job & 68 & 48.6 \\
\hline & To be employed in other private sectors & 5 & 3.6 \\
\hline \multirow{2}{*}{$\begin{array}{l}\text { 4. Got support from } \\
\text { Government }\end{array}$} & Yes & 70 & 83.3 \\
\hline & No & 14 & 16.7 \\
\hline \multirow{3}{*}{$\begin{array}{l}\text { 5.Have got enough money } \\
\text { to run the business plan }\end{array}$} & Yes & 33 & 39.3 \\
\hline & No & 51 & 60.7 \\
\hline & Omo microfinance & 46 & 54.8 \\
\hline \multirow[t]{3}{*}{ 6.Source initial finance } & Individual local lenders & 3 & 3.6 \\
\hline & From family support & 18 & 21.4 \\
\hline & Saved from own wage of daily work & 17 & 20.2 \\
\hline \multirow{2}{*}{$\begin{array}{l}\text { 7.Got support for daily } \\
\text { work access }\end{array}$} & Yes & 34 & 40.5 \\
\hline & No & 50 & 59.5 \\
\hline \multirow{2}{*}{$\begin{array}{l}\text { 8.Have got sufficient } \\
\text { working place }\end{array}$} & Yes & 34 & 40.5 \\
\hline & No & 50 & 59.5 \\
\hline \multirow{2}{*}{$\begin{array}{l}\text { 9. Field trained is compatible } \\
\text { with the job I am doing }\end{array}$} & Yes & 86 & 61.4 \\
\hline & No & 54 & 38.6 \\
\hline
\end{tabular}

Source: Researcher's Own Survey,2017 


\subsubsection{Integration between the Sawla TVET and MSE in view of Current Trainees and employed graduates}

Table 5: Integration status between the Sawla TVET College and MSEs according to the current trainees of the College $(\mathrm{n}=113)$

\begin{tabular}{llcc}
\hline \hline No Items & \multicolumn{1}{c}{ Responses } & Frequency & Percent \\
\hline \hline 1. Strong integration between Sawla & Yes & 42 & 37.2 \\
TVET and local MSE & No & 71 & 62.8 \\
\hline & Providing practical training in the work & 21 & 18.6 \\
2.If yes, the integration is & place & & \\
helped for & Technical support & 3 & 2.7 \\
& Experience sharing & 4 & 3.5 \\
& Initiating for self- employment & 14 & 12.4 \\
\hline & Strongly agree & 56 & 49.6 \\
3.TVET has great role for & Agree & 38 & 33.6 \\
industry extension or & Undecided & 15 & 13.3 \\
industrialization & Disagree & 2 & 1.8 \\
& Strongly disagree & 2 & 1.8
\end{tabular}

Source: Researcher's own survey in Sawla, 2017

Table 6: Summary of opinions of employed graduates on integration of the Sawla TVET College with the local stakeholders $(\mathrm{n}=140)$

\begin{tabular}{|c|l|c|c|}
\hline No Items & Responses & Frequency & Percent \\
\hline \multirow{2}{*}{$\begin{array}{l}\text { Sawla TVET has strong integration with } \\
\text { stakeholders }\end{array}$} & Strongly agree & 2 & 1.4 \\
& Agree & 16 & 11.4 \\
& Undecided & 29 & 20.7 \\
\hline 2. Have got support from TVET after graduation & Disagree & 56 & 40.0 \\
at work & Strongly disagree & 37 & 26.6 \\
\hline & No & 51 & 36.4 \\
3. Sawla TVET curriculum is compatible with the & Strongly agree & 89 & 63.6 \\
\hline local market & Agree & 20 & 14.3 \\
& Undecided & 79 & 56.4 \\
& Disagree & 26 & 18.6 \\
\hline
\end{tabular}

Researcher's own survey in Sawla, 2017

\subsubsection{Prospects of the TVET program and the Sawla TVET College}

Prospects, the chance of being successful in the future, of the college are addressed in this section. The study shows not only the challenges of the technical and vocational education and training program implementation; but also points out some opportunities that could be taken as helpful for the future prospect of the Sawla TVET College. As discussed above, lack of (financial, human and physical) resources, low (commitment, awareness and participation) of stakeholders, teachers' skill and knowledge gaps, weak integration between TVET institutions and stakeholders, and lack of well-organized management system seemed to provide gloomy future for the TVET college. However, there are also supportive local, national and international facts compounding the program.

\subsection{CONCLUSION}

From the findings of the study explained above, the following conclusions were drawn. The strategic importance and the objective of TVET is not yet clearly understood and accepted as a means for acquiring marketable knowledge and skill especially for the unemployed youths and thereby bringing solution to unemployment. This particular research area context requires a strong awareness creation and understanding development activities among the public from TVET, the local government, and other stakeholders for effective and efficient utilization of the institution.

The still prevailing negative perception of the society about the TVET together with the challenge of accessing job after training made many unemployed and untrained youths keep away from joining the TVET and affected the performance of the College. The employability of the TVET graduates is mostly challenged by the low access job opportunities and lack of appropriate support from the government and other stakeholders. The way towards job creation, especially for beginners in the work world is expected to be more facilitative, 
transparent and encouraging. In this regard, the findings show that the supportive package of the MSEs is not satisfactory which requires revisiting the performance of all elements in such a way that it should be all inclusive and effective. When the employability or job engagement of the trained youths is not successful, that causes trained unemployment and discourages the non-trained ones not to be enrolled and that affects the implementation of the TVET strategy in that- skilled manpower is produced but unemployment is not reduced yet.

As it stands now, the trainees are selective in streaming of different training fields in the College. There selectivity is related to job access after completing the training and their tendency to be employed in government offices than creating own job. It calls for extra effort to making jobs available in all fields of training by joint efforts of the TVET with the local government focusing the compatibility of the curriculum with the demand of the local economy to mitigate the problem. The tendency of graduates to be engaged in government works emanates from poor communication and awareness creation. It calls for corrective measures towards changing attitudes.

The TVET strategy advocates that the program is to be implemented through effective integration with stakeholders for the common benefit that the training institution performs well and the sectors capacity develops. The Sawla TVET College has weak integration with the stakeholders which in effect harmed the performance of the TVET, affected the industry extension support of the MSEs from the TVET, and made the awareness of the stakeholders about the college very low and has created the sense of less concern about the program. Therefore, the research observed the necessity developing strong relationships with stakeholders both for leadership aspects and to scale its performance in a way that it would achieve the expected objectives from the training program.

The finding shows that the college lacks some inputs and training facilities which make its internal capacity sub optimal. The college lacks higher level or the B-level and A-level trainers which lessens the quality of the current training and also limits the future upgrading opportunity of the College. Besides this, the college lacks the required quantity and well-functioning machines for some fields of training like the industry stream which is the government focus because of the direction of the country's economy towards industrialization/manufacturing. The raw material provision for the practical training is not sufficient and timely which negatively affects the quality of the skill training that needs every trainee to get chance for hands-on practice, which is an important expected characteristic feature of the TVET program. These all observed deficits of the College call for the timely intervention of the government and other mandated and interested stakeholders in order to make the institution to expand, to be effective, and efficient in all its endeavors.

\subsection{RECOMMENDATIONS}

In order to solve the challenges that hinder the effective and efficient performance of Sawla TVET College and to make it institution with better future prospects, the following recommendations are forwarded based on the quantitative and qualitative findings.

* Awareness creation and developing all-rounded understanding about the TVET program in the area;

* Increasing employability access for the trained youth;

* Developing strong integration between the TVET and its Potential stakeholders;

* Improving the internal capacity of the College

* Revitalizing and the attention of stakeholders to TVET;

* Developing better opportunities for brighter prospect;

\subsection{POLICY IMPLICATIONS}

* To develop the understanding of the youth and of the public at large about the TVET, it would be better to look for a mechanism to impart the concept of TVET program starting from certain level of the general education to make the youth aware about this highly valued program as early as possible; instead of communicating the case after the completion of the first cycle of secondary school. This would even potentially correct the attitude of the society towards the TVET program.

* The other point which seems to be reviewed is the source of trainers or teachers for the TVET. As that of the general education, the TVET institutions do not have teachers training institutions that produce appropriate professionals in accordance with the nature of the TVET. For temporary remedial, the TVETs get trainers from among their own graduates through testing their competences that are expected to be good performers. These trainers are being provided with and upgrading in service trainings in collaboration with colleges in the region. The regional bureau needs to do its level best to address the problem by coordinating these trainings in developing the curriculum in alignment with that of the national strategy and facilitating the involvement of the higher institutions. For further improvement of the TVET both in access and quality, setting direction to produce trainers for the TVET training programs at different levels is recommendable.

* The industry linkage and the TVET curriculum alignment with the local economies and job market also 
require policy reforms and attention. The TVET programming has to have the freedom to contextually align its Curriculum or fields of steams to the demand-driven job market and has to progressively revised in relation to the transformation of the economy and the job market.

\subsection{REFERENCES}

Adam Dasmani (2011). Challenges facing technical institute graduates in practical skills acquisition in the Upper East Region of Ghana.Asia-Pacific Journal of Cooperative Education, 2011, 12(2), 67-77

AtakiltHagos, Work Negash, and MelesewAsfaw, (2016).Evaluating the Implementation of Competence- Based Assessment and Certification System in TVET: the case of Ethiopia,Research on Humanities and Social science.vol. 6, No 9 (2016).

AtsedeKebede(2014).Assessment of linkage between Technical and Vocational Education and Training and Micro and Small enterprise:MAThesis in Management of Vocational Education,Addis Ababa University, Ethiopia.

EdenTeklay(2012).Analyzing the Labor Outcomes of TVET in Ethiopia: Implication of Challenges and Opportunities in Productive Self-employment of TVET Graduates; MA.Thesis,Institute of Social Studies, Netherlands, the Hague..

Essel, Eric A., S.M. Sumaila, and P.D. Yankson(2014).TVET Stigmatization in Developing Countries: Reality or Falacy? European center for Research Training and Development UK, vol.1, No.1, pp. 27-42. (www.eajournals.org)

FDRE, ESDP IV (2010). Education Sector Development Program IV, 2010/11-2014/15: Program Action Plan, Addis Ababa, Ethiopia.

FDRE, ESDP V (2015). Education Sector Development program V, 2015/16-2019/20: Program Action Plan, Addis Ababa, Ethiopia.

FitaAyalew(2014). Assessment of the Implementation of Industry Extension Services and Challenges: the case of selected Technical and Vocational Education and Training Institutions in Guraghe Zone.MAThesisin Management of Vocational Education. Addis Ababa,Ethiopia

GTP II (2015).The FDRE Growth and Transformation Plan.National Planning Commision, Sep,2015, Addis Ababa

H. Onderi, J. Ajowi, and G.Malala (2014). Restructuring Technical and Vocational Education and Training (TVET) for Sustainable Development in Sub-Saharan Africa:International Journal of Interdisciplinary Research and Innovations ISSN 2348-1226 (online) Vol. 2, Issue 1, pp: (40-45), Month: January-March 2014

LemmaDadi(2014). Effectiveness of Competency - Based TVET Curriculum in Ethiopia: the Case of TVET Institutions of Oromia Regional State. A Thesis Submitted to the Department of Curriculum and Teachers Professional Development Studies:Addis Ababa University.

Mgabhi (2016).Tracking TVET and Skills Development (TVETSD) Development in Swaziland: Prospects for Employment Creation; https://www.africa-youth.org/

M.Khatajabor, A. Minghat, and S.M., YahyaBuntat (2012).Sustainable leadership for Technical and Vocational Education and Training in Developing Nations: Faculty of Education, International Journal of Scientific and Research Publications, vol. 2, Issue 8, Aug 2012.

MoE(1994).Federal Democratic Republic of Ethiopia, Education and Training Policy: Addis Ababa, Ethiopia

MoE (2011).Fderal Democratic Republic of Ethiopia, Ministry of Education, Education Statistics Annual Abstract 2003 E.C (2010-11 G.C):Education Management Information System, Addis Ababa.

NahomFessehaye(2006). The Streaming of Students to TVET in Ethiopia: The Case of Two TVET Institutions in Addis Ababa In Fourth National Conference on Private Higher Education in Ethiopia, August 18 \& 19 , 2006

NasirMohammed Abdi(2014). The Attitude of $9^{\text {th }}$ and $10^{\text {th }}$ Grade Students towards Technical and Vocational Education and Training (TVET) in Addis Ababa City Administration Schools: Masters of Arts in Educational Planning and Management,Addis Ababa

OECD(2010). Vocational Education and Training in Germany, Strengths, Challenges and Recommendations: Directorate for Education, Education and Training policy Division.

Ogbunaya and Ekereobong (2015).Repositioning Technical and Vocational Education and Training (TVET) for Youths Employment and National Security in Nigeria: Journal of Education and Practice, vol. 6 No 32, 2015

Raimi L. and Akhuemonkhan (2014).Has Technical Vocational Education and Training (TVET) Impacted on Employability and National Development? The Macrotheme Review 3(2) Spring 2014, Nigeria.

Subrahmanayam G. (2014). Advancing TVET for Youth Employability and Sustainable Development: key findings from the global synthesis report, presentation at UNESCO-UNEVOC Global Forum 'Skills for work and lifepost 2015' Bonn Germany, 14, Oct 2014. 
Susan W. (2013).Stakeholders' Perception of Technical and Vocational Education and Training: the case of Keneyan Micro and Small Enterprises in the Motor Vehicle Service and Repair Industry. Edith Cowan University, http://ro.ecu.edu.au 59

UNESCO-IICBA (2011).The Role of Teacher Training in Technical and Vocational Education and Training (TVET) in Africa: International Institution for capacity Building in Africa, Newsletter vol.13, No. 2 Dec. 2011.

World Bank (2015). "Small and Micro Enterprises”, World Bank Group Review of Small Business activities: Washington, DC: WB.

Yamane T.(1967). Statistics: An introductory Analysis, $3^{\text {rd }}$ ed, New York: Harper and Row 1973

Yostena G. Yesus (2014). The Implementation of Technical Vocational Education and Training Program: the case of Nefas Silk and Tegbareid Polytechnic College, MA Thesis in Educational Planning and Management, Addis Ababa 